\title{
ベリリウム押出し材の高温強度に関する研究*
}

佐 藤千 之助** 奥 達 雄**
相 沢 作衛** 薄井沈 $*$ *

\section{Studies on the Mechanical Properties of Hot Extruded Beryllium at Elevated Temperatures}

by

\author{
Sennosuke Sato, Tatsuo Oku, Sakue Arzawa and Takeshi Usur \\ (Japan Atomic Energy Research Institute, Ibaraki)
}

The hot extruded beryllium of reactor grade purity was studied at elevated temperatures with respect to its tensile, hardness, elastic modulus and creep properties. The thus obtained results have been discussed in comparison with out previous report regarding hot rolled beryllium.

The hardness was regarded as a macroscopic measure for the temperature dependencies of critical slip mechanisms in single crystal. speed.

The elastic modulus up to $1000^{\circ} \mathrm{C}$ were determined by means of an ultrasonic pulse propagation

The creep tests were carried out in two ways, namely the stress increment method at constant temperatures among the room temperature to $700^{\circ} \mathrm{C}$ and the temperature cycling method of the triangular temperature variation between 350 and $600^{\circ} \mathrm{C}$ at constant loads. In the stress increment creep, the steady creep rate and the rupture life in the Larson-Miller diagrams agree reasonably with the corresponding data at The Brush Beryllium Co. by ordinary method. The relation of steady creep rate $\dot{\varepsilon}$ and the cycles-to-rupture $N_{R}$ in the temperature cycling creep was expressed as $\dot{\varepsilon} N_{R}{ }^{0.70}=$ constant. This equation is similar to the formura on strain controlled fatigue. The considerations in the temperature cycling creep of this material have been discussed in comparison with constant temperature creep.

(Received Dec. 15, 1966)

\section{1 緒 論}

ベリリウムは比重が非常に軽く $\left(1.84 \mathrm{~g} / \mathrm{cm}^{3}\right)$ ，その 割に機械的強度および弾性率が高いので特徴のある強 度部材として応用されている。ベリリウムはまた熱伝 導率 $\left(137 \mathrm{kcal} / \mathrm{mh}^{\circ} \mathrm{C}\right)$ が高く, 熱中性子吸収断面積が 非常に小さく, 中性子散乱断面積が大きいので原子炉 の減速材や反射材として広く実用され, 最近ではその すぐれた核的利点のため燃料被覆材としての開発研究 が行なわれている。しかし，その製造経験ならびに使 用経験が必ずしも豊富でなく，その高温の機械的性質 についても充分な資料がない，てのような現状から日 本原子力研究所としてもとの材料の金属学的ならびに 機械的性質について各方面の協力を得て共同作業が進 められている。

本研究は現在最も広く採用されている高温押出し法 によって製造した原子炉反射材用ベリリウム（原研 JMTR-C用) を用い，前報に引き続き高温における機

* 原稿受理 昭和 41 年 12 月 15 日

** 正会員 日本原子力研究所 茨城県那珂郡東海村
械的性質に関する研究の一環として行なわれた引張性 質, 弾性率, 硬度および温度一定応力漸増クリープお よび応力一定温度変動クリープ特性について報告する.

\section{2 供 試 材 料}

供試材料（日本碍子(保製）は Fig. 1 亿示すべリりウ ム電解フレークを原料とする粉末冶金工程において黒 鉛モールド中で $1100^{\circ} \mathrm{C}$ ておいて $30 \mathrm{~kg} / \mathrm{cm}^{2}$ 程度の熱

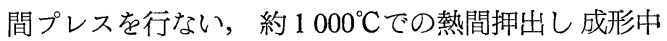
の酸化を防ぐため軟鋼のシースに入れて行なわれた。

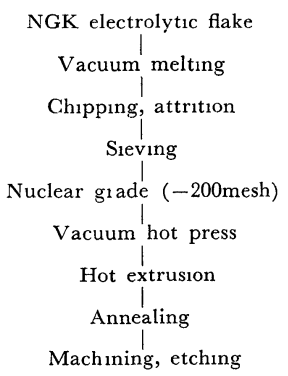

Fig. 1. Flow diagram of specimen preparation. 
Table I. Impurities in the hot extruded specimen (\%).

\begin{tabular}{|c|c|c|c|c|c|c|c|c|c|c|c|c|c|c|c|c|c|}
\hline Element & $\mathrm{BeO}$ & $\mathrm{Fe}$ & $\mathrm{Si}$ & Co. & Nifo & Mî́t & $M g$ & $\mathrm{Cr}^{2}=$ & $\mathrm{Ni}$ & $\mathrm{Al}$ & $\mathrm{L}_{11}$ & $\mathrm{Cu}$ & $\mathrm{Ag}$ & B & $\mathrm{Pb}$ & $\mathrm{Gd}$ & G \\
\hline Hot extruded $\mathrm{Be}$ & $\begin{array}{ll}1 & 61\end{array}$ & 0.135 & 0016 & 0.0005 & 0.0011 & 0.0070 & 0.033 & 0.094 & 0.0170 & 0.055 & 0.0002 & 0.0085 & $<0.001$ & $<0 \quad 0002$ & 0005 & $<000005$ & 0.09 \\
\hline
\end{tabular}

押出し後, 約 $800^{\circ} \mathrm{C}$ 、での焼なましを行ない，所要の機 械加工を行ない，ベリリウムの材料を得た，その寸法 は $85 \times 85 \times 850 \mathrm{~mm}$ である。

Table I はこの材料中の不純物の分析結果を示す. 不純物の総量は $2 \%$ 以下であって米国材料試験炉のべ リリウム反射材規格を満足している。なお，乙れら不 純物の量は The Brush Beryllium Co. (米) の原子炉 級に比べても少なく，特に $\mathrm{Fe}, \mathrm{Al}, \mathrm{Mg}$ は著しく低く， $\mathrm{Mn}, \mathrm{Si}$ の量は若干多いが，英国原子力庁 (UKAEA) 仕様に対応する程度である。

平均の程度は約 $15 \sim 20 \mu$ 程度であった。

本研究に使用したベリリウム試料片の形状は，前報 のもののほかに，Fig. 2 亿示すような高温弾性率およ

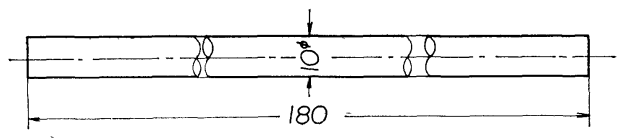

(a) Elastic modulus specimen

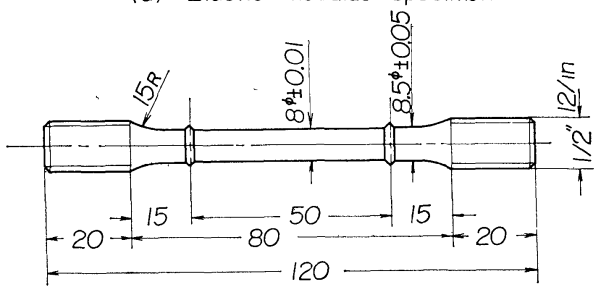

(b) Creep specimen

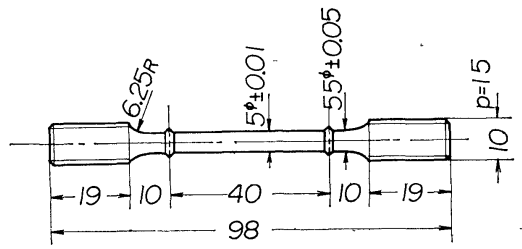

(c) Thermal fatigue specimen

Fig. 2. Shapes of test specimens.

びクリープ試験片を用いた。 クリープ試験片はすべて 表面首 $150 \mu$ ぐらいの化学的研摩を行ない表面加工首 の影響を無視できるようにした。この影響は前報に比 ベて比較的低温の結果に現われる.

高温弾性率およびクリープ試験片はすべて成型押出 し軸に平行に採取された。

\section{$\mathbf{3} \cdot \mathbf{1}$ 引張 試 験}

\section{3 実 験 方 法}

この測定は主として日本碍子姝において行なわれた。 試験片は小寸法の JIS 3 号型であった。 真空中にお いて $800^{\circ} \mathrm{C}$ 亿至る引張強度および伸びの測定を行なっ
た.

\section{$3 \cdot 2$ 硬 度 試 験}

$5 \times 5 \times 12 \mathrm{~mm}$ の角柱試片の端面を成型押出し軸に 平行および直角になるように採取し，ニコン高温微小 硬度計を用いて荷重 $300 \mathrm{~g}$ で，最高 $800^{\circ} \mathrm{C}$ 亿至る測定を 行なった.

\section{$3 \cdot 3$ 弾性率測定}

弾性率の測定は超音波の伝ぱ時間の測定により，そ の弾性縦波速度から算出した。この方法は高温におい ても適用され，超音波の発信子，受信子間に定弾性の 黒鉛中間材を介して; 試料の超音波速度を測定した。 試料は水平管状炉に横たえられ，アルゴンふん囲気中 にて昇温速度約 $2^{\circ} \mathrm{C} / \mathrm{min}$ で, 最高 $1000^{\circ} \mathrm{C}$ 亿至る測定 を行なった。

\section{$3 \cdot 4$ クリープ試験}

3・4・1 応力漸増法によるクリープ試験クリー プ試験は Fig. 2 (b) に示す平行部 $8 \phi \times 50 \mathrm{~mm}$ を有する 試片を用い，真空型引張クリープ試験機を用い，ゲー ジ間の長さの伸びを差動トランス方式で検出記録した. クリープ荷重は主として一定温度における応力漸増法 により，同一試片に $1 \sim 4$ 段の応力漸増を行なった. 各段階の実験は少なくとも約 $100 \mathrm{hr}$ の負荷時間をと り，少なくとも10時間以上の定常クリープを認めた後， 定常最小クリープ速度を求めた. 次の段階の測定は, 前の荷重を除去し, 応力休止として 3 時間の間, 真空 ベローズによる压縮応力を与えた後, その前の数倍の クリープ速度を与えるよう逐次荷重条件をか酷にさせ た. 最終段階では三次クリープ過程を経て破断するが, 破断時間の測定はその前後の試験による破断時間に及 ぼす影響は次のような理由で無視し，最終応力による 值を採用した。破断時間 $t_{r}$ が破断までのクリープひ ずみ速度 $\dot{\varepsilon}$ 総和によって決まると考え, 負荷応力お よび温度に無関係に次式

$$
t_{r} \cdot \dot{\varepsilon} \cong \text { const. }
$$

なる関係がなりたつととが認められいる。前後の主は 最終段階の数分の 1 であるから， $t_{r}$ には最高に見積っ て約20\%低下するととになる。しかし前段までのクリ ープはクリープ全過程の大半を占める二次クリープの 初期で中止しているから，結局のとてろ $t_{r}$ に及ぼす 影響は大きくとも数\%を出ないと考えられる. 前段ま でのひずみの総量もだいたいての程度であった．てう して得られた破断時間に関する Larson-Miller 線図は 他のデータに対しても妥当な結果を示している. 
$3 \cdot 4 \cdot 2$ 変温クリープ試験＼cjkstart次にベリリウム燃料 被覆材の原子炉の起動, 停止に対応する温度変動につ いてのクリープ性質を検討するため，熱疲労試験機を 用い，一定引張荷重を負荷させながら温度範囲 $600^{\circ}$ な いし $350^{\circ} \mathrm{C}$ 間で二等辺三角形の温度波を与えて 4 本 の実験を行なった，用いた試験片の形状はFig. 2 (c) に 示すような平行部 $5 \phi \times 40 \mathrm{~mm}$ の伸び検出用(差動トラ ンス式）のショールダを有するものである．装置の詳 細は省略するが, 温度変動は真空度 $10^{-3} \mathrm{mmHg}$ の才 ーダのふん囲気で傍熱方式により試片内の均熱性を保 持しつつ記録した，荷重はループ荷重計に差動トラン ス式荷重変換器を取り付け，温度変動下の膨張および 収縮に対しても一定になるよう自動調整を行なった。

\section{4 実験結果亡その考察}

\section{1 引張 性 質}

Fig. 3 は200〜 $800^{\circ} \mathrm{C}$ に至る引張強度と伸び特性を示 す. 引張強度には前報の圧延材の場合のような 400 $500^{\circ} \mathrm{C}$ 付近に波状を示さず比較的なだらかに低下する。

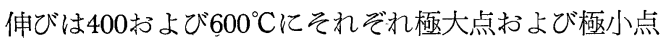
を示すような挙動を示した. $800^{\circ} \mathrm{C}$ にいては平均 37

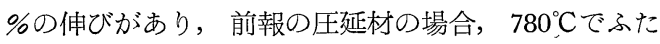
たびぜい化し，ほぼ室温のそれに低下したととと比較 し差異が認められる。

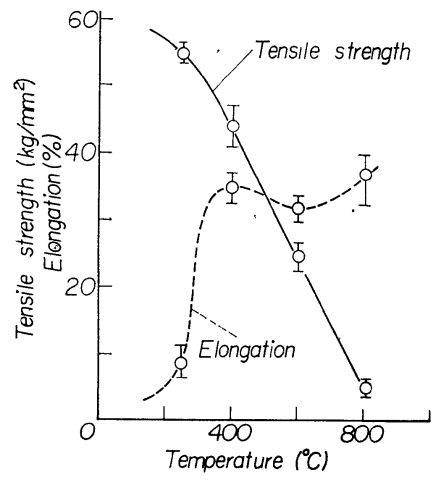

Fig. 3. Tensile strength as a function of temperature for hot extruded beryllium (offered by NGK Insulators Ltd.).

\section{2 硬度試験}

ベリリウム押出し軸に平行な面と垂直な面に対し微

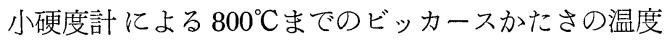
依存性は Fig. 4(a)に示すようになった。プロット点は 約10点の平均を示している. 押出し軸の影響としては 平行の面のほうがくぶん大きい值を示す. 前報と同 様, 降伏応力の温度依存性の式にならって硬度の対数 と絶対温度の逆数に対してプロットすれば, 実験範囲 において 3 段の折れ線で表わされる.Fig. 4 (b) はこれ を示す。乙れは前報で詳しく議論したように稠密六方 晶の低温側の第 1 段階が底面 (0001)すべりに, 第 2 段

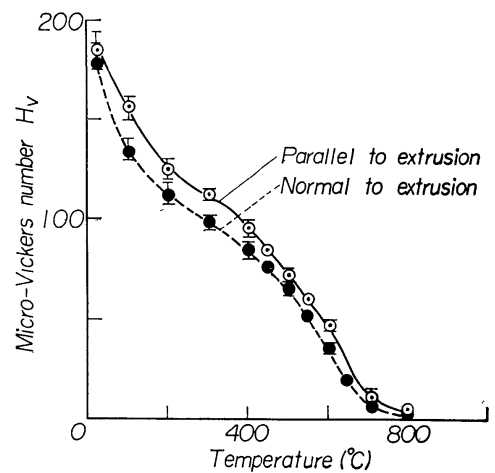

Fig. 4. (a) Vickers hardness number as a function of temperature for hot extruded beryllium.

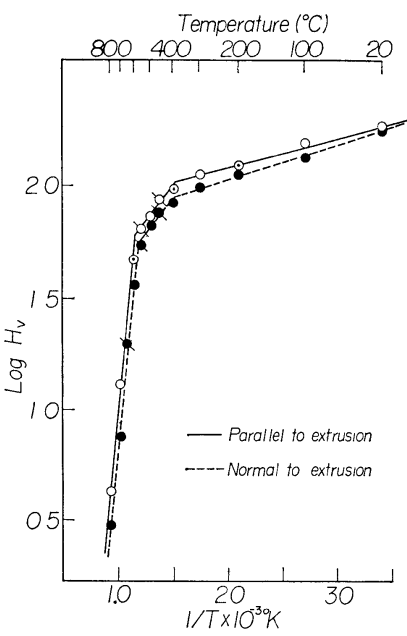

Fig. 4. (b) Logarithmic hardness number as a function of reciprocal absolute temperature for hot extruded beryllium.

階は底面と柱面 $(10 \overline{1} 0)$ すべ゙りが共存し，高温の第 3 段 階ではさらに錐面すべりや，不純物の拡散効果を含む 複雑な要素が変形に関与するものと考えられ，硬度に よっても微視的変形機構との対応が推定されるととは 興味ある事がらである.

前報の圧延材と比較し，全体としての硬度は低く， その折れ点の位置は粒度の比較的小さい場合の温度に 近い.

\section{4 -3 高温弾性率}

超音波パルス速度によって求めた熱間押出し材につ いての動的ヤング率の測定の結果は Fig. 5 亿示すとお りである. 室温の值は平均 $3.00 \times 10^{4} \mathrm{~kg} / \mathrm{mm}^{2}$ で, 前 述の圧縮試験による值とほぼ一致するばかりでなく， 従来の多くの報告ともよく一致する，音速度は $1.25 \times$ $10^{4} \mathrm{~m} / \mathrm{sec}$ (比重量 $\gamma=1.86 \mathrm{~g} / \mathrm{cm}^{2}$ ) であった，約 $200^{\circ} \mathrm{C}$ から $500^{\circ} \mathrm{C}$ 近傍まで比較的急減する傾向があり, $600^{\circ} \mathrm{C}$ 付近では室温の約 $2 / 3$ 程度になる。それ以上， $1000^{\circ} \mathrm{C}$ まではなだらかな減少がみられる。なお $1000^{\circ} \mathrm{C}$ 亿保 


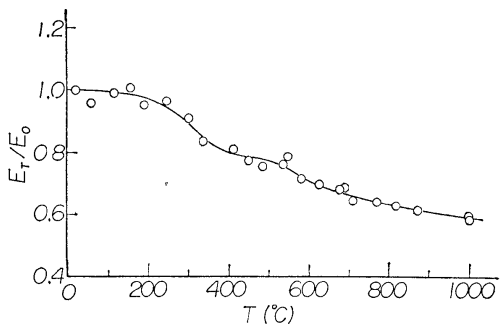

Fig. 5. Young's modulus by means of an ultrasonic pulse propagation as a function of temperature for hot extruded beryllium; $E_{0}=3.00 \times 10^{4} \mathrm{~kg}$ / $\mathrm{mm}^{2}$.

持した時間は約10分間でその後室温まで炉泠したが， 全体として薄い灰色になり，その上に白点状のスケー ルの発生をみた。

ポアソン比ンの温度依存性については未着手である が，剛性率 $G$ につてのBrush 社の資料によれば，約 $500^{\circ} \mathrm{C}$ までヤング率とほぼ等しい温度依存性を示し,そ れ以上では両者の比が近接する傾向がある。したがっ $\tau \nu=(E / 2 G)-1$ 等方的弾性論の式をかりに適用すれ ば $500^{\circ} \mathrm{C}$ 程度までは表 I の值が適用されるかもしれな いがもっっ高温ではさらに低下するてとが予想され よう. 高温ポアソン比の值は熱応力で問題になるので 高温ストレーン・ゲージを用いて測定を計画している。

\section{4・4 クリープ}

4.4・1 応力斬增法によるクリープ Fig. 6 は主 として応力漸増法による応力 $\sigma$ と最小クリープ速度 $\dot{\varepsilon}$ との関係を示す。図の白丸は応力漸増法における途中 のデータであり，黒丸はその最終クリープ強度のデー タである，両者は同一の直線上によくのる，したがっ てベリリウムについても測定範囲，室温ないし $700^{\circ} \mathrm{C}$ において近似的に指数クリープ則がなりたつ．実用さ れる $600^{\circ} \mathrm{C}$ 付近では $\dot{\varepsilon}=8.0 \times 10^{-9} \sigma^{8}$ と近似し，冷却材 ガス圧によるクリープの計算を行なった．図のいくつ かの応力レベルについて，クリープの活性化エネルギ Qを求めてみると，高温で低応力側 $\left(2 \mathrm{~kg} / \mathrm{mm}^{2}\right)$ で $100 \mathrm{kcal} / \mathrm{mol}$, 低温で高応力側 $\left(20 \mathrm{~kg} / \mathrm{mm}^{2}\right)$ で約 40

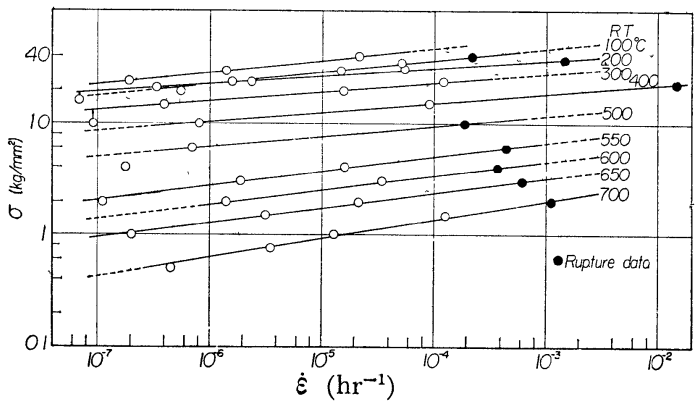

Fig. 6. Steady creep rate as a function of applied stress for the hot extruded beryllium. $\mathrm{kcal} / \mathrm{mol}$ で，温度によって一様な值にはならないて とが示された。ベリリウムについては Kaufmann ら によるクリープ破壊データから求めた活性化エネルギ は $65 \mathrm{kcal} / \mathrm{mol}$ である。また，Dorn によれば自己拡 散の活性化エネルギとクリープのそれとは相互に対応 する関係があり，純金属の融点に対するクリープまた は自己拡散の活性化エネルギの関係は対数線図におい て一直線で表わされる。したがって，いまべリリウム の融点 $1553^{\circ} \mathrm{K}$ に対してての推定によると約 $60 \mathrm{kcal} /$ $\mathrm{mol}$ になる。 この值はここに求めたクリープの值の平 均に近いが，低温高応力側では高く，高温低応力側で は低い:てれは定常クリープに対する回復理論のよう に，低温側では交差すべりが律速過程であり，高温側 では転位の上昇運動と熱的自己拡散をあわせ考光ると すると，ベリリウムの場合には実験した温度の範囲に わたり一義的なクリープの変形機構によらないととが 理解される。最近, Petrequim は鋳造べリリウム（粒 度約 $140 \mu)$ について $Q=60 \sim 70 \mathrm{kcal} / \mathrm{mol}$ の值を示し， ての材料の高温クリープは自己拡散によって支配され ないと述べている。

Fig. 7 の実線は Larson-Miller 流の master rup-

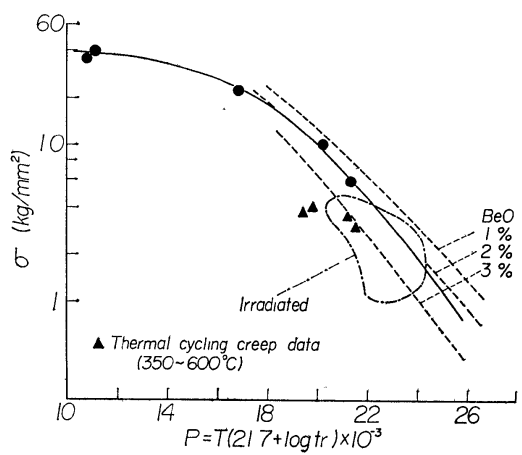

Fig. 7. Master creep rupture curve for hot extruded beryllium and the comparison with data by The Brush Beryllium Co.

ture curve である. ての場合の破断時間 $t_{r}, \mathrm{hr}$ と 温度 $T^{\circ} \mathrm{K}$ のパラメータ $P=T\left(c+\log t_{r}\right)$ 中の定 数 $c$ 值は普通約 20 と仮定されるが，乙てでは温度無 限大，すなわち $1 / T=0$ 亿おけるべリリウムの理論的 分裂速度に対応する光速度わよびベリリウムの原子間 距離から21.7とした。図の点線はBrush 社製ベリリ ウムのデータを整理したもので, $\mathrm{BeO}$ の含有量が 1 , 2 および $3 \%$ の場合を示す. 本研究の場合は約 $2 \%$ に 対応するから約 $400{ }^{\circ} \mathrm{C}$ 以上ではよく一致している。 そ の他, 高温加圧成型材, 押出し材につき中性子照射を 行なったものについての断片的なデータを図中にまと めて示した。. 中性子照射を行なうと同一のパラメータ $P$ 亿対応する応力が著しく低下する傾向が認められる 


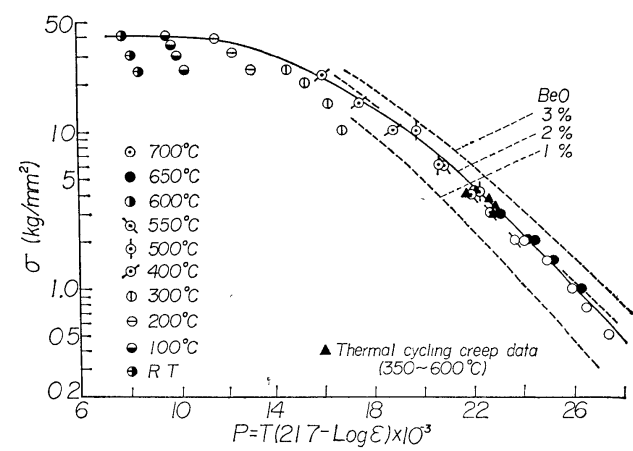

Fig. 8. Master creep curve for hot extruded beryllium and the comparison with data by The Brush Beryllium Co.

が，現在のとてろまだ系統的な研究が行なわれていな い. なお，クリープ破断についてのとの整理法を最小 クリープ速度宅に適用し，いわゆる master creep curve を求めると Fig. 8 亿示すようになる. 図の黒丸 は途中の応力のそれである. 図の点線は同様に Brush 社のデータであるが， $400^{\circ} \mathrm{C}$ 以上では対応する $\mathrm{BeO} 2$ \%の場合とよく一致する。しかし， $400^{\circ} \mathrm{C}$ 以下の低温 では本実験の黑丸と白丸の間に著しい差異があり，同 一曲線上にのらない，宅の差異は応力漸増法によると きは往々にして遷移クリープの值を測定し， い值をとりがちであるが，たとえば $300{ }^{\circ} \mathrm{C}$ の場合には 低応力の場合には約 100 倍にもなり, 実験の精度上,

予想をはるかに上回る。したがって，ての master creep curve の整理法はこの比較的低温度範囲に対す る適用を制限するものであろう。

4.4.2 温度変動下のクリープ Fig. 9 は 600〜 $350^{\circ} \mathrm{C}$ 間の三角波形温度変動下のクリープ性質の 記録 例を示す。最高および最低温度の保持時間は 1 分で, 1 サイクルの周期は 32.5 分であった。 サイクルの進行 に対する一般的傾向は温度一定のクリープの場合之同 様に遷移，第二次および第三次グリープを示した。

Fig. 10 は負荷応力 $\sigma$ に対する破壊サイクル $N_{R}$ の関

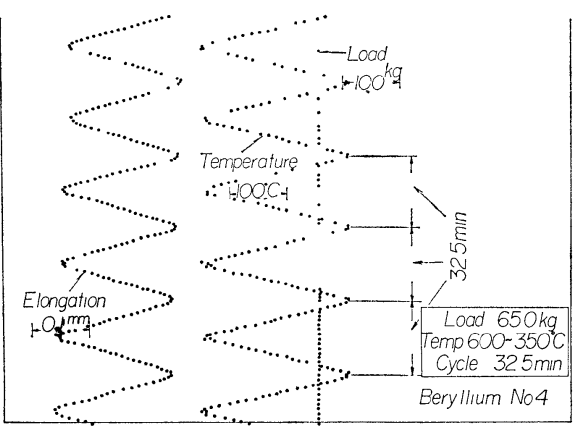

Fig. 9. A record of creep under temperature-cycling between 350 and $600^{\circ} \mathrm{C}$ for hot extruded beryllium.

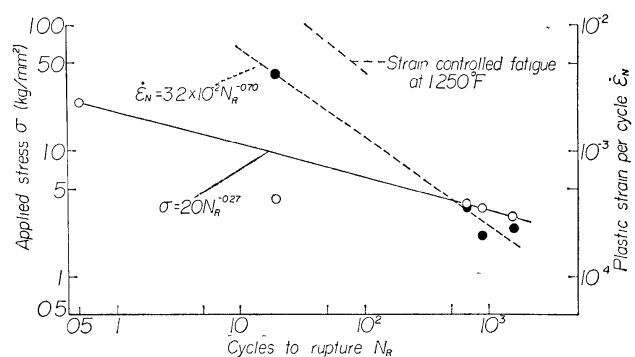

Fig. 10. Applied constant stress and steady creep rate or plastic strain per cycle as a function of cyles-to-rupture under temperature cycling between 350 and $600^{\circ} \mathrm{C}$ for hot extruded beryllium. The chain line shows a strain-cycling fatigue data at $661^{\circ} \mathrm{C}$ for a beryllium after Swindeman and Douglas.

係および 1 サイクルあたりの定常クリープ速度 $\dot{\varepsilon}_{N} に$ 対する $N_{R}$ の関係をあわせ示す。 $N_{R}=0.5$ 亿対する $\sigma$

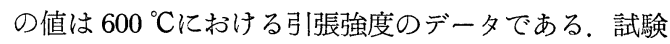
数が少ないがおおおよそ

$$
\begin{aligned}
& \sigma=20 N_{R}^{-0.27} \\
& \dot{\varepsilon}_{N} \cdot N_{R}{ }^{0.7}=3.2 \times 10^{-2}
\end{aligned}
$$

の関係がある、 $\dot{\varepsilon}_{N}$ はクリープの過程によっていくぶ ん変化するが，ひずみ制御型疲労試験における塑性ひ ずみ振幅に対応するものとすれば，Coffin らによる $\dot{\varepsilon}_{N} N_{R}{ }^{\alpha}=$ const. の形式と類似するようにみえる. しか し，Coffin らによる指数 $\alpha$ の值は 0.5 とされ，高温の 熱疲労では 0.6 ぐらいになる例が多い. 本研究の場合 では0.70であっていくぶん大きめな傾向を示す。べリ リウムについての熱疲労のデータは少ないが，Swindeman and Douglas の $1250^{\circ} \mathrm{F}$ におけるデータでは, Fig. 10 亿示すように， $\alpha=0.81$ となっている. したが って, ベリリウムの場合の本研究のような比較的高温 の塑性ひずみ振幅ではかなり大きめの $\alpha$ を示すものと 考えてよい.

次に破断サイクル数を周期 $\mathrm{hr}$ で除し，乙れを破断 時間 $t_{r}$ とし，Fig. 7 の定温クリープの場合の master rupture curve と比較すると温度を最高保持温度 ( $T$ $\left.=873^{\circ} \mathrm{K}\right)$ そとっても図示のように定温クリープの場 合よりも破断時間にして数分の 1 亿低下するてとがわ かる.

次に Fig. 11 は負荷応力に対する単位時間あたりの 第二次定常クリープ速度 $\dot{\varepsilon}$ を求め, 点線に示す前節の 温度一定の場合と比較したものである. 変温クリープ の場合は通例, 固体状態力学方程式による相当温度を 求めると, 平均温度よりも高く, 最高温度に近い温度 を示すととが多い，本研究の $350 \sim 650^{\circ} \mathrm{C}$ の温度変動で も平均温度 $\left(475^{\circ} \mathrm{C}\right)$ よりも最高保持温度, つまり 600 ○にでく近接した結果が得られた。 また，乙の変動温 


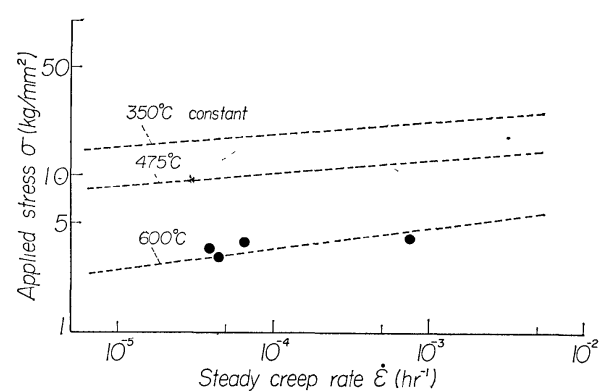

Fig. 11. Relation of applied stress and steady creep data per hour under temperature-cycling between 350 and $600^{\circ} \mathrm{C}$ for hot extruded beryllium. The dotted lines show the constant temperature creep data from Fig. 6.

度クリープのデータを, 温度を最高保持温度 $(T=873$

$\left.{ }^{\circ} \mathrm{K}\right)$ として Fig. 8 の master creep curve にプロッ トすると，定温クリープの曲線とほぼ一致する。なお， ベリリウム押出し材の室温から $700^{\circ} \mathrm{C}$ 亿至る 1000 回の サーマルサイクル試験によると押出し軸に平行および 直角方向に対しそれぞれ約 $1 \%$ の収縮および膨張が観 測されているが， 600 C以下ではそれが無視しうると とが知られている。実用上，原子煸内ベリリウムは最 高温度 $600{ }^{\circ} \mathrm{C}$ 亿保持される時間の長い温度波形を示す ことから，実験範同では本材料による場合はクリープ 速度に対しては，相当温度によらなくとも設計上最高 温度をめやすとして取り扱ってさしつかえなさそうで あるが，破断時間に関しては低下するととがあると結 論される。

$$
5 \text { 結 論 }
$$

ベリリウムは㱏性にそしいととがこの材料の最大弱 点とされ，特に原子然料被覆材としては室温付近でも 延性のあるベリリウムまたはての合金を製造するとと が当面の大きな課題となっている，本研究は原子炉反 射材として広く適用されている押出し材につき高温に おける機械的性質につき検討を行なったもので，ここ に得られた結果を要約すると次のようになる.

\section{5・1 引張性質}

押出しベリリウムの軸方向引張強度は前報の圧延材 よりもいくぶん大きい值を示したがてれは押出し比に も関連がある．伸びについては室温において押出し軸 に平行方向にはかなりの延性があるが，直角方向には $1 \sim 1.5 \%$ 程度であり, 高温では $400^{\circ} \mathrm{C}$ 付近に極大点が あり，全体としてらくだのてぶ状になる。

\section{$5 \cdot 2$ 硬 度}

これは降伏応力または流動応力の一尺度と考えられ るが，硬度の対数と試験温度（絶対温度）の逆数の関 係は室温ないし $800{ }^{\circ} \mathrm{C}$ 間で 3 段の折れ線で示され， その各段が単結晶のすべり限界応力とほぼ対応する関
係が得られた。

\section{こ・3 弾监率}

超音波パルスの伝ぱ速度を測定する方式により $1000^{\circ} \mathrm{C}$ 亿至るヤング率の温度依存性を明らかにした。 室温のデータは従来のそれと類似し， 600 ㄷでは室温 の約 $2 / 3$ 亿低下する.

\section{$5 \cdot 4$ クリープ特性}

測定範囲室温〜 $700^{\circ} \mathrm{C}$ にいて，温度一定における いわゆる応力漸増法によって実験したが，指数クリー プ則が成立する。実験結果は Larson-Miller 法によ って整理し，試験温度，負荷応力，クリープ速度およ び破断時間の間の関係を検討した. $600^{\circ} \mathrm{C} て ゙ 10000$ 時間 および 5000 時間に対するクリープ破猿応力はそれぞ

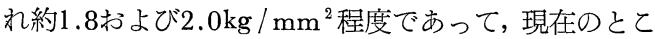
ろの材料の強度設計上ほとんど応力のかからないよう な構造にすることが要請される。

また，原子炉の起動停止に対応する温度変動下のク リープ挙動を検討し， $600 \sim 350^{\circ} \mathrm{C}$ 間の三周波では600 ${ }^{\circ} \mathrm{C}$ 温度一定のクリープに近いクリープ速度を示し, サ イクルあたりの塑性ひずみと破壊サイクル数の間には, $\dot{\varepsilon}_{N} N_{R}{ }^{0} 70=3.2 \times 10^{-2}$ なる関係が得られた。

終わりにのぞみ，本研究は原研と日本碍子(株との共 同研究の一環として行なわれたものであるととを明ら かにし，貴重な試料の準備に協力された同社研究所西 垣課長はじめ関係の皆様に感謝の意を表する。

(昭和41年11月 24 日 日本材料学会第 8 回高缊強变シンポシウムに て講演）

\section{参 考 文 献}

1) Darwin, G.E., and J.H. Buddery, "Beryllium" (1960) Butterwarths Sci. Publ.

2）原子力金属㦝談会，“ベリリウム”（1961）新金属 協会

3）佐藤千之助, 奥達雄, 怞原俊一, JAERI-memo, 2208 (1966).

4）佐藤千之助，奥達雄，薄井洸，材料， 16， 194 (1967).

5）佐藤千之助，宮園昭八郎，機械学会誌，69，1146 (1966).

6) Sato, S., and S. Miyazono, Garbon, 2, 103 (1964).

7）平修二，大南正瑛，日本機械学会論文集，27, No. 176, 387 (1961).

8) Kawasaki, M., and M. Sasagawa, Thırd Intern, Conf. on the Peaceful Uses of Atomic Energy, Geneva, Paper, No. 431 (1964).

9) The Brush Beryllium Co., "Beryllium in Aero/ Space Structure" (1964).

10) Tuer, G.L., and A.R. Kaufmann, "The Metal 
Beryllium", Ghapt. 7, ASM, (1955).

11) Oku, T., S. Sato, and T. Fujimura, Nucl. Struct. Engg., (Amsterdam) 2, 282 (1965).

12) Kaufmann, A.R., P. Gordon, and D.W. Lillie, Trans. ASM, 42, 785 (1950).

13) Dorn, J.E., "Proc. Greep and Fructure of Metals at High Temperature", N.P.L., p. 89 (1956).

14) Petrequim, P.P., Intern. Conf. Beryllium Metall., Greroble, Paper, No. 39 (1965).

15) O'Rourke, R.G., et al., AEG Rept. COO-312 (1956).
16) Bush, S.H., "Irradiation Effects in Structural and Cladding Materials" (1965).

17) Goffin, L.F., ASTM STP, No. 151 (1953); Trans. ASME, 76, 931 (1954) ; ASTM STP. No. 165 (1954).

18）鵜戸口英善，高圧力，4，681（1966).

19) Swindeman, R.W., and D.A. Douglas, J. Basic Engg. 81, 203 (1959).

20）平修二，大南正瑛ら，日本機械学会論文集，27, 373,381 および 387 (1961).

21）西垣進，新金属工業，p. 167（1966年 6 月号).

American Society for Testing and Materials (ASTM) そおいて Temperature Effects に関する Special Technical Publication (STP) としては次のようなものがある.

STP 165 Symposium on Effect of Cyclic Heating and Stressing on Metals at Elevated Temperatures.

STP 260 Literature Surveys on Influence of Stress Concentrations at Elevated Temperatures and Effect of Non-Steady Load and Temperature Conditions on the Greep of Metals. (1959)

STP 287 Symposium on Low-Temperature Properties of High-Strength Aircraft and Missile Materials (1961)

STP 302 Symposium on Evaluation of Metallic Materials in Design for Low-Temperature Service.

STP 303 Symposium on Elevated Temperature Compression of Sheet Materials. (1962)

STP 374 Irreversible Effects of High Pressure and Temperature on Materials. (1965)

STP 387 Behavior of Materials at Cryogenic Temperatures. (1966)

Fatigue に関するSTP としてはたとえば次のものがある.

STP 237 Basic Mechanisms of Fatigue. (1959)

STP 274 Symposium on Fatigue of Aircraft Structures. (1960)

STP 284 Symposium on Acoustical Fatigue. (1961)

STP 338 Symposium on Fatigue Tests of Aircraft Structures-Low Cycle, Full-Scale and Helicopters. (1963)

STP 381 Symposium on Fracture Toughness Testing and Its Applications. (1965)

また Erosion, Corrosion に関するものとしては次のものがあげられる.

STP 307 Symposium on Erosion and Cavitation. (1962)

STP 290 Twenty-year Atmospheric Corrosion Investigation of Zinc-Coated and Uncoated Wire and

Wire Products. (1961)

STP 368 Corrosion of Zirconium Alloys. (1965)

STP 397 Stress-Corrosion Cracking of Titanium. (1966) 